\title{
On the atmospheric degradation of pyruvic acid in the gas phase
}

\author{
Abdelwahid Mellouki ${ }^{\mathrm{a}, *}$, Yujing $\mathrm{Mu}^{\mathrm{b}}$

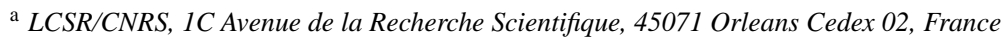 \\ ${ }^{\mathrm{b}}$ Research Center for Eco-Environmental Sciences, Academia Sinica, Beijing 100085, China
}

Received 29 March 2002; accepted 13 August 2002

\begin{abstract}
The pulsed laser photolysis-laser induced fluorescence (PLP-LIF) technique has been used to measure the rate constant for the gas phase reaction of $\mathrm{OH}$ radicals with pyruvic acid $\left(\mathrm{CH}_{3} \mathrm{C}(\mathrm{O}) \mathrm{C}(\mathrm{O}) \mathrm{OH}\right)$ in the temperature range 273-371 $\mathrm{K}$. The data obtained were found to be well represented by the conventional Arrhenius expression: $k_{\mathrm{PA}}=(4.9 \pm 1.9) \times 10^{-14} \exp [(276 \pm 123) / T] \mathrm{cm}^{3} \mathrm{molecule}^{-1} \mathrm{~s}^{-1}$, and at $298 \mathrm{~K}, k_{\mathrm{PA}}=(1.2 \pm 0.4) \times 10^{-13} \mathrm{~cm}^{3}$ molecule ${ }^{-1} \mathrm{~s}^{-1}$. In addition, the UV-Vis absorption cross-sections of pyruvic acid were measured in the wavelength range $290-380 \mathrm{~nm}$ at $298 \mathrm{~K}$; the obtained values are compared with literature ones. Using the PLP-LIF system, the photolysis of pyruvic acid was found to yield $\mathrm{OH}$ radicals with a quantum yield of $5 \pm 3 \%$ at $355 \mathrm{~nm}$. Evidence was also found for the $\mathrm{OH}$ production from the photolysis of pyruvic acid using a set of black lamps as the light source. The data obtained confirm that the photolysis is the major gas phase atmospheric loss process of pyruvic acid.
\end{abstract}

(C) 2003 Elsevier Science B.V. All rights reserved.

Keywords: Degradation; Photolysis; Pyruvic acid

\section{Introduction}

Pyruvic acid $\left(\mathrm{CH}_{3} \mathrm{C}(\mathrm{O}) \mathrm{C}(\mathrm{O}) \mathrm{OH}\right)$ is one of the most abundant ketoacids present in the atmosphere. Its presence has been reported in aerosols, rainwater and in the gas phase in urban atmosphere as well as in remote continental and marine areas (e.g. [1-3]). It is a product of the biogenic emissions and the photochemical oxidation of natural organic compounds such as isoprene and cresols (e.g. $[1,4])$. Talbot et al. reported average daytime gas phase concentrations of pyruvic acid over central Amazonia, during the wet season, of $25 \pm 15$ and $15 \pm 15 \mathrm{ppt}$ in the forest canopy and free troposphere, respectively [5]. The concentrations are expected to be higher during the dry season. Baboukas et al. measured a mixing ratio of $1.1 \pm 1.0 \mathrm{pptv}$ above the Atlantic Ocean [3]. The measurements performed by Andreae et al., showed that the concentrations of pyruvic acid and formic acid were highly correlated, with typical formic-to-pyruvic ratios of 10-30 in the gas phase, 20-30 in rain and 2-10 in aerosols [1]. Similarly to other organic acids, pyruvic acid is expected to be removed from the atmosphere through different homogeneous and heterogeneous processes. Therefore, it is expected to play a role in the precipitation acidity.

\footnotetext{
* Corresponding author. Fax: +33-238257505.

E-mail address: mellouki@cnrs-orleans.fr (A. Mellouki).
}

Available data indicate that the main gas phase loss process of pyruvic acid in the atmosphere is photolysis; the contribution of the gas phase reaction with $\mathrm{OH}$ radicals is considered to be a negligible removal process since the reaction rate constant is estimated to be $\leq 5 \times 10^{-14} \mathrm{~cm}^{3}$ molecule ${ }^{-1} \mathrm{~s}^{-1}[6,7]$. However, the $\mathrm{OH}$ reaction rate constant with pyruvic acid has never been directly measured. In this work, we report the first measurement of the rate constant for the reaction of $\mathrm{OH}$ with pyruvic acid in the temperature range $273-371 \mathrm{~K}$. In addition, we report the UV-Vis spectra of this ketoacid as well as evidence for the production of $\mathrm{OH}$ radicals from its photolysis at $\lambda=351$ and $355 \mathrm{~nm}$ and by using a set of black lamps.

\section{Experimental and results}

\subsection{OH rate constant measurement}

The pulsed laser photolysis-laser induced fluorescence (PLP-LIF) technique was used to measure the reaction rate constant of $\mathrm{OH}$ with pyruvic acid and the $\mathrm{OH}$ quantum yield production from its photolysis at $355 \mathrm{~nm}$. This experimental set-up has been described in detail previously [8], hence, only a brief presentation of the method and the procedures to extract the data are given here. 
In the kinetic study, $\mathrm{OH}$ radicals were generated by photolysis of $\mathrm{HONO}$ at $355 \mathrm{~nm}$ and detected by exciting the $Q_{1}(1)\left(\mathrm{A}^{2} \Sigma \leftarrow \mathrm{X}^{2} \Pi\right)$ line at $282 \mathrm{~nm}$ by a beam from a frequency-doubled Nd:YAG pumped dye laser at a right angle to the photolysis beam. The resulting $\mathrm{OH}$ fluorescence was collected perpendicular to both the photolysis and probe beams by a photomultiplier tube, whose signal was fed to a gated charge integrator and then sent to a computer for data analysis.

All kinetic experiments were carried out under pseudofirst-order conditions with [pyruvic acid] $\gg[\mathrm{OH}]_{0}$, the initial concentration of $\mathrm{OH}$ being $[\mathrm{OH}]_{0}<4 \times$ $10^{11}$ molecules $\mathrm{cm}^{-3}$. The temporal profiles of $[\mathrm{OH}]$, therefore, followed the pseudo-first-order rate law:

$[\mathrm{OH}]_{t}=[\mathrm{OH}]_{0} \exp \left(-k^{\prime} t\right), \quad$ where $k^{\prime}=k_{\mathrm{PA}}[\mathrm{PA}]+k_{0}^{\prime}$

[PA] is the pyruvic acid concentration and $k_{\mathrm{PA}}$ is the rate coefficient for its reaction with $\mathrm{OH}$ radicals. The decay rate, $k_{0}^{\prime}$, is the first-order decay of $\mathrm{OH}$ in the absence of pyruvic acid. The value of $k_{0}^{\prime}$ is essentially the sum of the reaction rate of $\mathrm{OH}$ with its precursor, $\mathrm{HONO}$, and the diffusion rate of $\mathrm{OH}$ out of the detection zone. The second-order rate coefficients $k_{\mathrm{PA}}$ values were obtained from the slopes of plots of $\left(k^{\prime}-k_{0}\right)$ versus PA concentrations. Examples of typical plots $\left(k^{\prime}-k_{0}\right)$ versus [PA] obtained are presented in Fig. 1. Pyruvic acid was flowed directly from a bubbler or from a bulb where it was premixed with helium and its concentration calculated from mass flow rates, temperature and pressure in the cell. Helium (UHP certified to >99.9995\%), nitrogen (99.9995\%), both from Alphagas, were used without purification. $\mathrm{HONO}$ was produced in situ by reacting $\mathrm{NaNO}_{2}(0.1 \mathrm{M})$ with dilute $\mathrm{H}_{2} \mathrm{SO}_{4}(10 \%)$ contained in a stirred round bottomed flask. The effluent from the flask

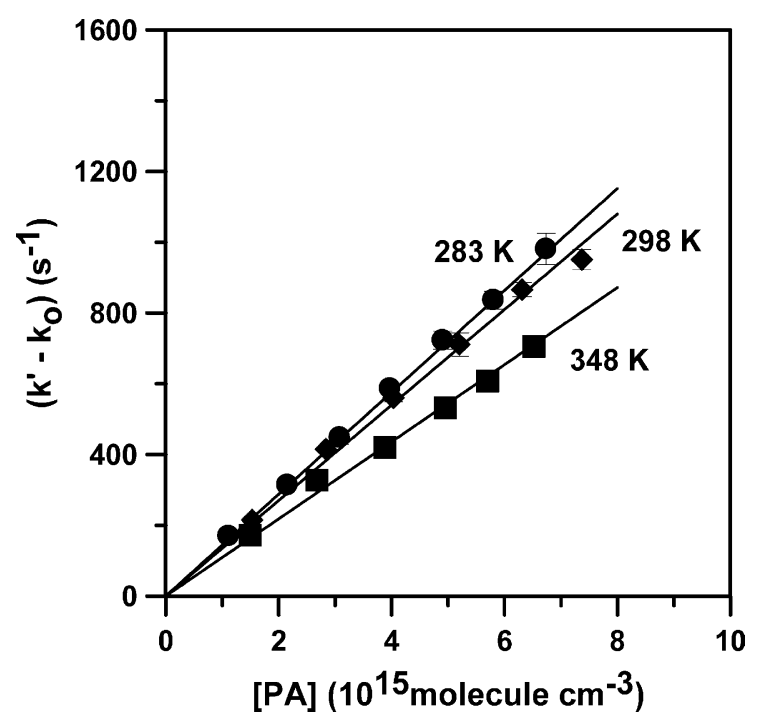

Fig. 1. Typical plots of $k^{\prime}-k_{0}$ vs. [pyruvic acid]. The solid line is the linear least-squares fit to the data.
Table 1

Rate constants for the reaction of $\mathrm{OH}$ with $\mathrm{CH}_{3} \mathrm{C}(\mathrm{O}) \mathrm{C}(\mathrm{O}) \mathrm{OH}$ in the range $273-371 \mathrm{~K}$

\begin{tabular}{|c|c|c|c|}
\hline$T(\mathrm{~K})$ & $\begin{array}{l}{\left[\mathrm{CH}_{3} \mathrm{C}(\mathrm{O}) \mathrm{C}(\mathrm{O}) \mathrm{OH}\right]} \\
\left(10^{15} \text { molecules cm } \mathrm{cm}^{-3}\right)\end{array}$ & $\begin{array}{l}k^{\prime}-k_{0} \\
\left(\mathrm{~s}^{-1}\right)\end{array}$ & $\begin{array}{l}(k \pm 2 \sigma) \times 10^{13} \\
\left(\mathrm{~cm}^{3} \text { molecule }^{-1} \mathrm{~s}^{-1}\right)\end{array}$ \\
\hline 273 & $1.01-4.19$ & $174-619$ & $1.35 \pm 0.17$ \\
\hline 283 & $1.11-6.74$ & $170-981$ & $1.46 \pm 0.1$ \\
\hline 298 & $1.53-7.37$ & 215-951 & $1.35 \pm 0.13$ \\
\hline 298 & $1.21-10.7$ & $108-1262$ & $1.16 \pm 0.13$ \\
\hline 298 & $4.42-21.4$ & $226-941$ & $0.98 \pm 0.08$ \\
\hline 298 & $0.05-2.25$ & $17-237$ & $1.14 \pm 0.08$ \\
\hline 323 & $0.87-6.55$ & 79-904 & $1.38 \pm 0.09$ \\
\hline 348 & $1.34-6.88$ & $172-705$ & $1.11 \pm 0.16$ \\
\hline 348 & $1.49-7.48$ & $150-732$ & $1.08 \pm 0.08$ \\
\hline 371 & $0.98-5.88$ & $112-507$ & $0.88 \pm 0.05$ \\
\hline 371 & $0.86-4.80$ & $102-507$ & $1.13 \pm 0.17$ \\
\hline
\end{tabular}

was swept into the cell by a known flow of helium. Pyruvic acid $(>98 \%)$ was obtained from Fluka and further purified by repeated freeze-pump-thaw cycles and fractional distillation before use. GC-MS analysis of pyruvic acid showed the presence of less than $1 \%$ of acetic acid as impurity.

All experiments were performed at a total pressure of around 100 Torr. The results obtained in the temperature range $273-371 \mathrm{~K}$ are given in Table 1 and plotted in the Arrhenius form in Fig. 2. They were fitted to the conventional Arrhenius form, $k=A \exp (-E / R T)$. From un-weighted least squares analysis, the Arrehnius expression of the rate constant is: $k_{\mathrm{PA}}=(4.9 \pm 1.9) \times$ $10^{-14} \exp [(276 \pm 123) / T] \mathrm{cm}^{3}$ molecule ${ }^{-1} \mathrm{~s}^{-1}$, where the quoted errors are $A \sigma_{\ln A}$ and $\sigma_{E / R}$ for $A$ and $E / R$, respectively. At $298 \mathrm{~K}$, the rate constant value is taken as the average of the data obtained at this temperature: $k_{\mathrm{PA}}=$ $(1.2 \pm 0.4) \times 10^{-13} \mathrm{~cm}^{3}$ molecule ${ }^{-1} \mathrm{~s}^{-1}$. The quoted error is $2 \sigma$ to which we have added $15 \%$ due mainly to the uncertainty in the measured concentration of pyruvic acid.

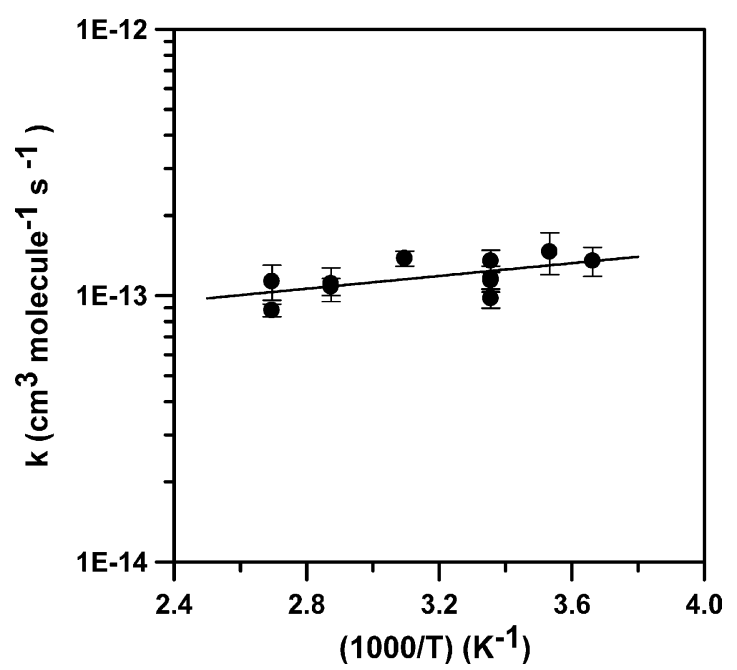

Fig. 2. Plot of $k_{\mathrm{PA}}$ vs. 1000/T. The solid line is the linear least-squares fit to all data. 


\subsection{UV absorption spectra}

This was measured in a $100 \mathrm{~cm}$ long and $2.5 \mathrm{~cm}$ diameter absorption cell through which a collimated output of a $30 \mathrm{~W}$ $\mathrm{D}_{2}$ lamp was passed and focused onto the entrance slit of the spectrophotometer equipped with a 1800 grooves $\mathrm{mm}^{-1}$ grating and a 1024 element diode array detector [9]. The spectrum was divided into three overlapping regions of about $40 \mathrm{~nm}$ in the range $290-380 \mathrm{~nm}$. The wavelength scale of the spectrometer was calibrated using the emission lines from low-pressure $\mathrm{Hg}(253.7,313.2,365 \mathrm{~nm})$ pen-ray lamp and was accurate to $0.1 \mathrm{~nm}$. Absorption cross-sections were calculated using the Beer-Lambert's law:

$\sigma(\lambda)=\frac{-\ln \left[I(\lambda) / I_{0}(\lambda)\right]}{L C}$

where $\sigma(\lambda)$ is the absorption cross-section $\left(\mathrm{cm}^{2}\right.$ molecule $\left.{ }^{-1}\right)$ at the wavelength $\lambda, L$ the path length in $\mathrm{cm}$, and $C$ is the concentration in molecules $\mathrm{cm}^{-3}$. $I$ and $I_{0}$ are the light intensities with and without PA in the absorption cell, respectively. The reference spectrum $I_{0}$ was recorded after purging the absorption cell with helium. The spectrum $I$ was measured when a fixed pressure of pyruvic acid was flowed through the absorption cell. For each $40 \mathrm{~nm}$ region of the spectrum, absorption measurements were made at six different pressures in the range $0.2-1$ Torr. $I_{0}$ was recorded before and after each $I$ measurement. The pressure measurements were made using a capacitance manometer operating in the range $0-10$ Torr.

The spectrum obtained at $298 \pm 3 \mathrm{~K}$ is shown in Fig. 3 and the cross-section values are listed in Table 2 in $1 \mathrm{~nm}$ intervals. The precision of the experimental cross-sections was calculated at each wavelength using the standard deviation for different measurements. In general, the standard deviation of the measured absorption cross-section was better than $10 \%$. In addition to the statistical errors on the measured cross-section, the systematic ones mainly due to the con-

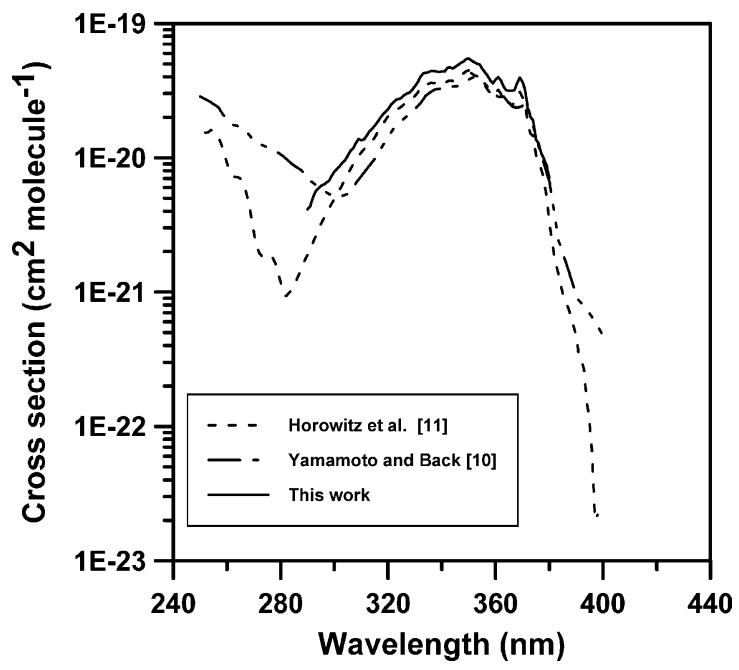

Fig. 3. Absorption cross-sections of pyruvic acid.
Table 2

The UV absorption cross-sections of pyruvic acid at $298 \pm 3 \mathrm{~K}$

\begin{tabular}{|c|c|c|c|c|c|}
\hline $\begin{array}{l}\lambda \\
(\mathrm{nm})\end{array}$ & $\sigma^{\mathrm{a}}$ & $\begin{array}{l}\lambda \\
(\mathrm{nm})\end{array}$ & $\sigma^{\mathrm{a}}$ & $\begin{array}{l}\lambda \\
(\mathrm{nm})\end{array}$ & $\sigma^{\mathrm{a}}$ \\
\hline 290 & $4.13 \times 10^{-21}$ & 320 & $2.30 \times 10^{-20}$ & 350 & $5.48 \times 10^{-20}$ \\
\hline 291 & $4.35 \times 10^{-21}$ & 321 & $2.48 \times 10^{-20}$ & 351 & $5.32 \times 10^{-20}$ \\
\hline 292 & $5.06 \times 10^{-21}$ & 322 & $2.59 \times 10^{-20}$ & 352 & $5.15 \times 10^{-20}$ \\
\hline 293 & $5.61 \times 10^{-21}$ & 323 & $2.7 \times 10^{-20}$ & 353 & $5.03 \times 10^{-20}$ \\
\hline 294 & $5.89 \times 10^{-21}$ & 324 & $2.74 \times 10^{-20}$ & 354 & $4.98 \times 10^{-20}$ \\
\hline 295 & $6.17 \times 10^{-21}$ & 325 & $2.80 \times 10^{-20}$ & 355 & $4.61 \times 10^{-20}$ \\
\hline 296 & $6.30 \times 10^{-21}$ & 326 & $2.93 \times 10^{-20}$ & 356 & $4.35 \times 10^{-20}$ \\
\hline 297 & $6.52 \times 10^{-21}$ & 327 & $3.00 \times 10^{-20}$ & 357 & $4.09 \times 10^{-20}$ \\
\hline 298 & $6.75 \times 10^{-21}$ & 328 & $3.07 \times 10^{-20}$ & 358 & $3.77 \times 10^{-20}$ \\
\hline 299 & $7.32 \times 10^{-21}$ & 329 & $3.21 \times 10^{-20}$ & 359 & $3.59 \times 10^{-20}$ \\
\hline 300 & $7.87 \times 10^{-21}$ & 330 & $3.41 \times 10^{-20}$ & 360 & $3.82 \times 10^{-20}$ \\
\hline 301 & $8.27 \times 10^{-21}$ & 331 & $3.65 \times 10^{-20}$ & 361 & $3.98 \times 10^{-20}$ \\
\hline 302 & $8.70 \times 10^{-21}$ & 332 & $4.01 \times 10^{-20}$ & 362 & $3.76 \times 10^{-20}$ \\
\hline 303 & $9.16 \times 10^{-21}$ & 333 & $4.23 \times 10^{-20}$ & 363 & $3.38 \times 10^{-20}$ \\
\hline 304 & $9.58 \times 10^{-21}$ & 334 & $4.30 \times 10^{-20}$ & 364 & $3.18 \times 10^{-20}$ \\
\hline 305 & $1.04 \times 10^{-20}$ & 335 & $4.35 \times 10^{-20}$ & 365 & $3.15 \times 10^{-20}$ \\
\hline 306 & $1.13 \times 10^{-20}$ & 336 & $4.43 \times 10^{-20}$ & 366 & $3.15 \times 10^{-20}$ \\
\hline 307 & $1.18 \times 10^{-20}$ & 337 & $4.43 \times 10^{-20}$ & 367 & $3.19 \times 10^{-20}$ \\
\hline 308 & $1.29 \times 10^{-20}$ & 338 & $4.39 \times 10^{-20}$ & 368 & $3.58 \times 10^{-20}$ \\
\hline 309 & $1.38 \times 10^{-20}$ & 339 & $4.37 \times 10^{-20}$ & 369 & $3.96 \times 10^{-20}$ \\
\hline 310 & $1.35 \times 10^{-20}$ & 340 & $4.39 \times 10^{-20}$ & 370 & $3.69 \times 10^{-20}$ \\
\hline 311 & $1.37 \times 10^{-20}$ & 341 & $4.39 \times 10^{-20}$ & 371 & $3.21 \times 10^{-20}$ \\
\hline 312 & $1.46 \times 10^{-20}$ & 342 & $4.67 \times 10^{-20}$ & 372 & $2.31 \times 10^{-20}$ \\
\hline 313 & $1.57 \times 10^{-20}$ & 343 & $4.72 \times 10^{-20}$ & 373 & $2.01 \times 10^{-20}$ \\
\hline 314 & $1.64 \times 10^{-20}$ & 344 & $4.61 \times 10^{-20}$ & 374 & $1.90 \times 10^{-20}$ \\
\hline 315 & $1.73 \times 10^{-20}$ & 345 & $4.75 \times 10^{-20}$ & 375 & $1.37 \times 10^{-20}$ \\
\hline 316 & $1.84 \times 10^{-20}$ & 346 & $4.91 \times 10^{-20}$ & 376 & $1.28 \times 10^{-20}$ \\
\hline 317 & $1.97 \times 10^{-20}$ & 347 & $5.07 \times 10^{-20}$ & 377 & $1.08 \times 10^{-20}$ \\
\hline 318 & $2.10 \times 10^{-20}$ & 348 & $5.21 \times 10^{-20}$ & 378 & $9.81 \times 10^{-21}$ \\
\hline \multirow[t]{2}{*}{319} & $2.20 \times 10^{-20}$ & 349 & $5.42 \times 10^{-20}$ & 379 & $8.71 \times 10^{-21}$ \\
\hline & & & & 380 & $7.06 \times 10^{-21}$ \\
\hline
\end{tabular}

a In $\mathrm{cm}^{2}$ molecule -1

centration measurements, contribute to overall uncertainty. This latter is estimated to be $\pm 10 \%$.

Fig. 3 shows also the spectra reported previously by Yamamoto and Back [10] and very recently by Horowitz et al. [11]. Yamamoto and Back reported only the relative absorption spectrum at $358 \mathrm{~K}$ which was normalized by Horowitz et al. by using the value of the cross-section at $350 \mathrm{~nm}(\sigma=$ $3.82 \times 10^{-20} \mathrm{~cm}^{2}$ molecule ${ }^{-1}$ ) quoted by Berges and Warneck [12]. The three spectra show a similar shape, however, the one reported by Yamamoto and Back is clearly shifted to the red in the range $240-300 \mathrm{~nm}$ compared to that of Horowitz et al. The cross-sections values measured in this work are systematically higher than those obtained recently by Horowitz et al. This difference could reach a factor two (for wavelengths lower than $295 \mathrm{~nm}$ for example) and is typically around $20-30 \%$ in the wavelength range $305-370 \mathrm{~nm}$. At least part of this discrepancy could be attributed to the difficulties of handling the pyruvic acid sample and measurement of the concentrations.

\subsection{Photodissociation of pyruvic acid}

Experiments were conducted by using two complementary techniques, the PLP-LIF system and a smog chamber. 
We describe first the experiments performed with PLP-LIF system which was the same as that used to measure the $\mathrm{OH}$ reaction rate constant and described briefly above.

\subsubsection{Photodissociation of PA using PLP-LIF system}

During the kinetic experiments presented above, preliminary checks showed the occurrence of a fluorescence signal when pyruvic acid was photolyzed in helium at $355 \mathrm{~nm}$, in the absence of $\mathrm{HONO}$ (the $\mathrm{OH}$ precursor used in our experiments). An excitation spectrum was recorded in the range $281.9-282.5 \mathrm{~nm}$ following the photolysis of pyruvic acid at 351 and $355 \mathrm{~nm}$ and was found to be similar to that of $\mathrm{OH}$ radicals obtained when pyruvic acid was replaced by HONO. Therefore, a series of experiments was conducted to measure the $\mathrm{OH}$ production quantum yield resulting from the photolysis of pyruvic acid at $355 \mathrm{~nm}$.

The primary quantum yield for $\mathrm{OH}$ production, $\Phi(\mathrm{OH})$, at $355 \mathrm{~nm}$ was determined relative to that of HONO. Experiments were performed in 100 and 300 Torr of helium in the absence and presence of up to $1.1 \times 10^{16}$ molecules $\mathrm{cm}^{-3}$ of $\mathrm{H}_{2} \mathrm{O}$, and in 30-50 Torr of nitrogen to measure the total yield of $\mathrm{OH}$, including $\mathrm{OH}\left(\mathrm{A}^{3} \Sigma\right)$ and any vibrationally excited $\mathrm{OH}\left(\mathrm{X}^{2} \Pi\right)$ by quenching the excited species to $\mathrm{OH}\left(\mathrm{X}^{2} \Pi\right.$, $v^{\prime \prime}=0$ ). The concentration of $\mathrm{OH}$ radicals, $[\mathrm{OH}]$, was measured at several different delay times after the photolysis pulse to generate a temporal profile. The initial $\mathrm{OH}$ signals were obtained from the $t=0$ intercept of $\ln \left(f^{t}\right)$ versus reaction time, $t$, plots (where $f^{t}=S^{t}-B, B$ is the background excited by the probe laser and $S^{t}$ is the signal at time $t$ ). The temporal profile of $\mathrm{OH}$ produced upon photolysis is governed mainly by its reaction with the photolyte, HONO or pyruvic acid, in large excess over $\mathrm{OH}$ :

$$
\begin{aligned}
& \mathrm{OH}+\mathrm{HONO} \rightarrow \text { products }\left(k_{\mathrm{HONO}}\right) \\
& \mathrm{OH}+\mathrm{CH}_{3} \mathrm{C}(\mathrm{O}) \mathrm{C}(\mathrm{O}) \mathrm{OH} \rightarrow \text { products }\left(k_{\mathrm{PA}}\right)
\end{aligned}
$$

In addition, the $\mathrm{OH}$ radicals are lost via diffusion out of the detection zone. This first order loss process has a rate coefficient $k_{\mathrm{d}}$. Therefore, the $\mathrm{OH}$ temporal profile is given by the equation:

$[\mathrm{OH}]_{t}=[\mathrm{OH}]_{0} \exp \left(-k^{\prime} t\right)$

where

$k^{\prime}=k_{\mathrm{d}}+k_{\mathrm{HONO}}[\mathrm{HONO}] \quad$ or $\quad k^{\prime}=k_{\mathrm{d}}+k_{\mathrm{PA}}[\mathrm{PA}]$

Fig. 4 shows an example of the obtained $\mathrm{OH}$ profiles following photolysis of HONO or pyruvic acid. By variation of pyruvic acid concentrations, the rate coefficient for the reaction of $\mathrm{OH}$ with PA was measured at 100 Torr of $\mathrm{He}$, the rate constant obtained was $k_{\mathrm{PA}}=(1.5 \pm 0.5) \times$ $10^{-13} \mathrm{~cm}^{3}$ molecule ${ }^{-1} \mathrm{~s}^{-1}$. This value can be considered in agreement with that measured directly using $\mathrm{HONO}$ as $\mathrm{OH}$ source $\left(k=(1.2 \pm 0.4) \times 10^{-13} \mathrm{~cm}^{3}\right.$ molecule $\left.{ }^{-1} \mathrm{~s}^{-1}\right)$.

For the $\mathrm{OH}$ quantum yield measurements, $\mathrm{HONO}$ was first photolyzed and the initial signal, $f_{\mathrm{HONO}}^{0}$ was determined. HONO was then replaced by PA and photolysis was repeated

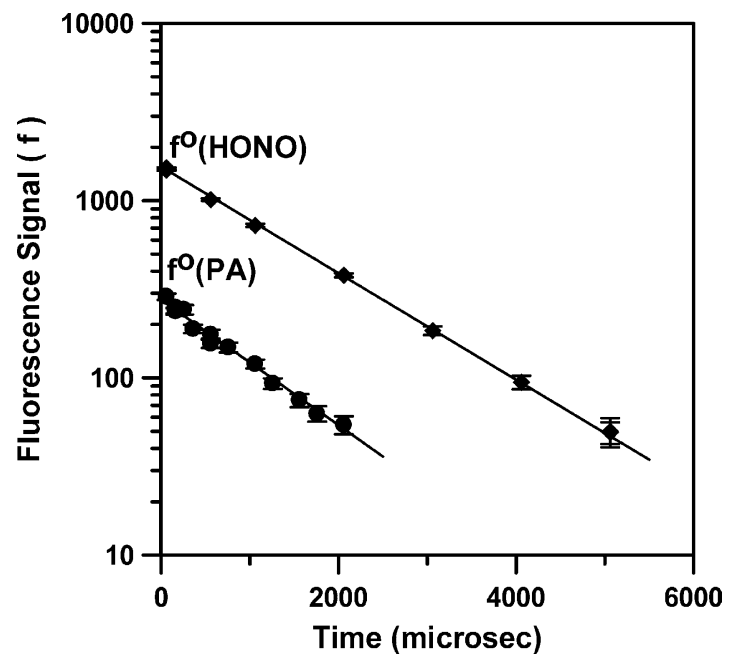

Fig. 4. Example of the obtained $f^{0}$ (OH LIF signal) vs. reaction time. Initial conditions are: [HONO] $=1.3 \times 10^{14}$, [pyruvic acid $]=3.58 \times 10^{15}$ molecules $\mathrm{cm}^{-3}$ at $P=110$ Torr of $\mathrm{He}$, and $E_{355}=8 \mathrm{~mJ}$.

to obtain $f_{\mathrm{PA}}^{0}$. Back to back photolysis runs of $\mathrm{HONO}$ and PA can be rationed to obtain:

$\frac{f_{\mathrm{PA}}^{0}}{f_{\mathrm{HONO}}^{0}}=\frac{\left[\Phi_{\mathrm{PA}}(\mathrm{OH}) \sigma_{\mathrm{PA}} E_{\mathrm{PA}}[\mathrm{PA}]\right]}{\left[\Phi_{\mathrm{HONO}}(\mathrm{OH}) \sigma_{\mathrm{HONO}} E_{\mathrm{HONO}}[\mathrm{HONO}]\right]}$

where $E_{\mathrm{PA}}$ and $E_{\mathrm{HONO}}$ are the photolysis-laser fluences for the $\mathrm{PA}$ and $\mathrm{HONO}$ runs $\left(E_{\mathrm{PA}}=E_{\mathrm{HONO}}\right.$ in the range $4-8 \mathrm{~mJ}),[\mathrm{PA}]$ and $[\mathrm{HONO}]$ were in the ranges $(1.0-12.9)$ $\times 10^{15}$ and $(0.7-8) \times 10^{14}$ molecules $\mathrm{cm}^{-3}$, respectively. $\sigma_{\mathrm{PA}}$ and $\sigma_{\mathrm{HONO}}$ are the absorption cross-sections at $355 \mathrm{~nm}\left(\sigma_{\mathrm{PA}}=4.61 \times 10^{-20} \mathrm{~cm}^{2}\right.$ molecule ${ }^{-1}$, from this work, $\sigma_{\text {HONO }}=36.4 \times 10^{-20} \mathrm{~cm}^{2}$ molecule ${ }^{-1}$ [13], and $\left.\Phi_{\mathrm{HONO}}(\mathrm{OH})=1\right)$. The primary quantum yield was then obtained from a plot of the ratio of the initial signals $\left(f_{\mathrm{PA}}^{0} / f_{\mathrm{HONO}}^{0}\right)$ versus $[\mathrm{PA}] /[\mathrm{HONO}]$. An example of the obtained plot is given in Fig. 5.

The experimental conditions and the obtained quantum yields are summarized in Table 3. An average value of $\Phi(\mathrm{OH})=0.05 \pm 0.01$ is derived from all experiments. An additional systematic error of $\pm 30 \%$ is added to the final

Table 3

Quantum yields, $\Phi_{\mathrm{PA}}(\mathrm{OH})$, in the $355 \mathrm{~nm}$ photolysis of pyruvic acid at $298 \pm 3 \mathrm{~K}$

\begin{tabular}{lll}
\hline$P($ Torr $)$ & Slope $^{\mathrm{a}}$ & $\Phi(\mathrm{OH})$ \\
\hline $100 / \mathrm{He}$ & $(7.1 \pm 0.4) \times 10^{-3}$ & $0.05 \pm 0.01$ \\
$300 / \mathrm{He}$ & $(7.2 \pm 0.7) \times 10^{-3}$ & $0.06 \pm 0.01$ \\
$30 / \mathrm{N}_{2}$ & $(5.9 \pm 0.6) \times 10^{-3}$ & $0.05 \pm 0.01$ \\
$50 / \mathrm{N}_{2}$ & $(8.4 \pm 0.9) \times 10^{-3}$ & $0.07 \pm 0.01$ \\
$\left.100 / \mathrm{He}\left(\left[\mathrm{H}_{2} \mathrm{O}\right]=4.4 \times 10^{15}\right]\right)^{\mathrm{b}}$ & $(4.5 \pm 0.6) \times 10^{-3}$ & $0.04 \pm 0.01$ \\
$\left.100 / \mathrm{He}\left(\left[\mathrm{H}_{2} \mathrm{O}\right]=2.8 \times 10^{15}\right]\right)^{\mathrm{b}}$ & $(4.6 \pm 0.5) \times 10^{-3}$ & $0.04 \pm 0.01$ \\
$\left.100 / \mathrm{He}\left(\left[\mathrm{H}_{2} \mathrm{O}\right]=1.1 \times 10^{16}\right]\right)^{\mathrm{b}}$ & $(5.7 \pm 0.6) \times 10^{-3}$ & $0.05 \pm 0.01$ \\
$\left.100 / \mathrm{He}\left(\left[\mathrm{H}_{2} \mathrm{O}\right]=1.1 \times 10^{16}\right]\right)^{\mathrm{b}}$ & $(7.6 \pm 0.9) \times 10^{-3}$ & $0.06 \pm 0.01$ \\
\hline
\end{tabular}

${ }^{\text {a }}$ Error in the slope is $2 \sigma$.

${ }^{\mathrm{b}}$ In molecules $\mathrm{cm}^{-3}$. 


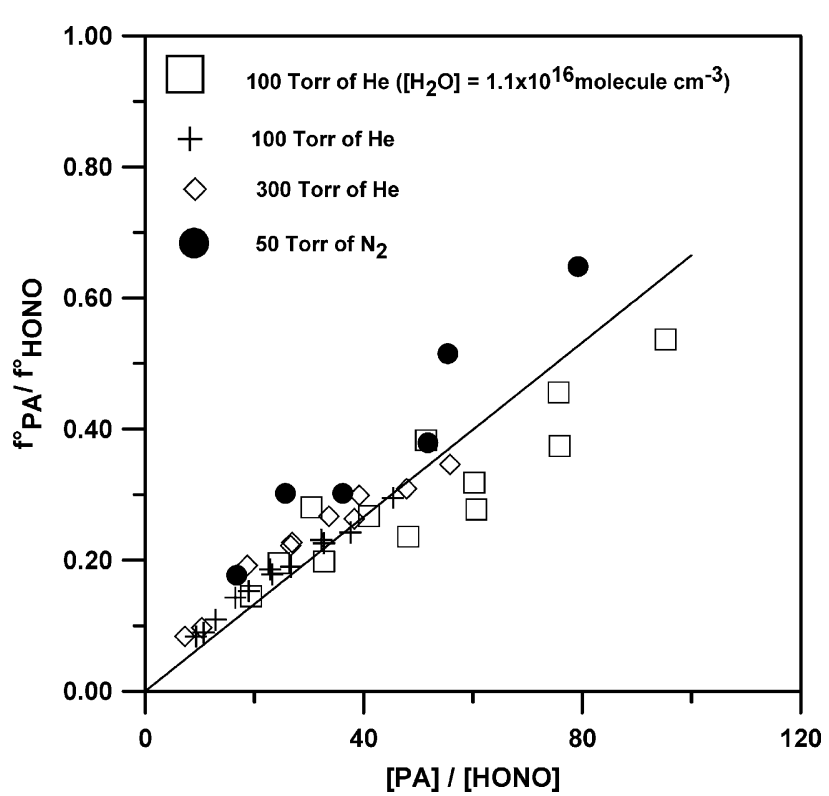

Fig. 5. Plot of the $f_{\mathrm{PA}}^{0} / f_{\mathrm{HONO}}^{0}$ vs. [PA]/[HONO] obtained in different experimental conditions at $298 \pm 3 \mathrm{~K}$.

value of the quantum yield to include uncertainties on the concentration measurements of pyruvic acid and HONO and their cross-sections which leads to: $\Phi(\mathrm{OH})=0.05 \pm 0.03$.

\subsubsection{Photodissociation of PA using black lamps}

A series of independent experiments was conducted in the smog chamber to confirm the production of $\mathrm{OH}$ radicals from the photolysis of pyruvic acid using black lamps. The set-up used for this purpose consisted of a 1001 Teflon bag surrounded by six black lamps (Philips, TL 20W/05) with irradiation in the range $300-460 \mathrm{~nm}$ and a maximum intensity at $365 \mathrm{~nm}$. Measured amounts of reagents were flushed from calibrated bulbs into the Teflon bag through a stream of ultra pure air (Alphagaz). The photoreactor was then filled to its full capacity at atmospheric pressure with ultra pure air. A gas chromatograph-flame ionization detector (GC-FID) was used for the quantitative analysis of the reactants. The gas mixtures were sampled at several reaction times and the change in concentration of the compounds was achieved from integration of the chromatogram peaks. Chromatographic separation was achieved by using a DB-1 capillary column.

Two experiments were conducted with mixtures of isoprene/2,3-dimethyl-1,3-butadiene/pyruvic acid, and one where 2,3-dimethyl-1,3-butadiene was replaced by 1,3-pentadiene. First, blank runs were performed which consisted of: (1) isoprene and the other diene (2,3-dimethyl-1,3-butadiene or 1,3-pentadiene) were irradiated for more than $2 \mathrm{~h}$; no change was observed in the concentrations of the two compounds; (2) pyruvic acid was then added to the mixtures and left for more than $2 \mathrm{~h}$ without irradiation. Here too, no change was observed in the concentrations of the compounds in the mixture. When the lamps were switched on for the same duration the concentration of the two dienes were found to decay by $10-15 \%$. The observed decrease of these compounds was attributed to the reaction of $\mathrm{OH}$ radicals (produced from the photolysis of PA) with isoprene and the other diene present in the mixture (2,3-dimethyl-1,3 butadiene or 1,3-pentadiene):

$\mathrm{OH}+$ isoprene $\rightarrow$ products $\quad\left(k_{\text {isoprene }}\right)$

$\mathrm{OH}+$ diene $\rightarrow$ products $\quad\left(k_{\text {diene }}\right)$

Assuming that the two compounds are only consumed by reaction with $\mathrm{OH}$, it can be shown that

$\ln \left\{\frac{[\text { diene }]_{0}}{[\text { diene }]_{t}}\right\}=\frac{k_{\text {diene }}}{k_{\text {isoprene }}} \ln \left\{\frac{[\text { isoprene }]_{0}}{[\text { isoprene }]_{t}}\right\}$

where the subscripts 0 and $t$ indicate concentrations before irradiation and at time $t$, respectively. Fig. 6 shows an example of the data obtained from the photolysis of isoprene/2,3-dimethyl-1,3-butadiene/pyruvic acid mixture. The ratios $k_{\text {diene }} / k_{\text {isoprene }}$, derived from different experiments were: $k_{\text {diene }} / k_{\text {isoprene }}=1.4 \pm 0.2$, and $k_{\text {diene }} / k_{\text {isoprene }}=$ $1.5 \pm 0.2$ for isoprene/2,3-dimethyl-1,3-butadiene and $k_{\text {diene }} / k_{\text {isoprene }}=1.2 \pm 0.2$ for isoprene/1,3-pentadiene runs. An independent experiment was performed where $\mathrm{OH}$ radicals were produced from the photolysis of $\mathrm{H}_{2} \mathrm{O}_{2}$ at $254 \mathrm{~nm}$ in the presence of isoprene and 2,3-dimethyl-1,3-butadiene. The obtained ratio $k_{\text {diene }} / k_{\text {isoprene }}$, was $1.3 \pm 0.2$ which is in good agreement with the reported above. These ratios are also to be compared with those derived from the literature data: $k(\mathrm{OH}+$ isoprene $)=1.01 \times 10^{-10}[14], k(\mathrm{OH}+$ 2,3-dimethyl-1,3-butadiene) $=1.25 \times 10^{-10}$ [15] and, $k(\mathrm{OH}+1,3$-pentadiene $)=1.03 \times 10^{-10} \mathrm{~cm}^{3}$ molecule $^{-1} \mathrm{~s}^{-1}$ [15]. From these data, the ratios $k_{\text {diene }} / k_{\text {isoprene }}$ are calculated to be: 1.2 and 1.02 for 2,3-dimethyl-1,3-butadiene and 1,3-pentadiene, respectively.

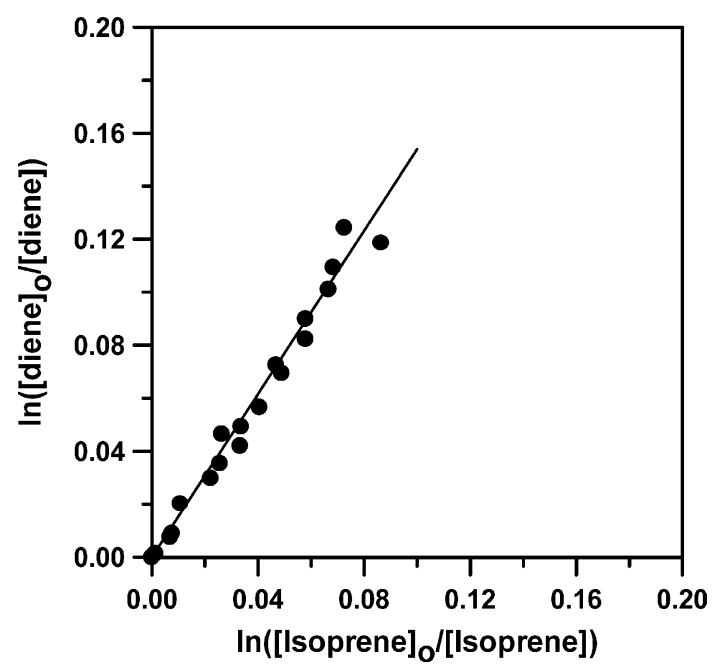

Fig. 6. An example of the decay of isoprene and 2,3-dimethyl1,3-butadiene during photolysis of pyruvic acid using black lamps. 
The photolysis of pyruvic acid has been studied by different groups using a variety of conditions and light sources. Yamamoto and Back [10] used a $\mathrm{Hg}-\mathrm{Xe}$ high-pressure arc lamp to study the photolysis of PA at 366,345 and $320 \mathrm{~nm}$ while Berges and Warneck [12] used a xenon arc lamp centered at $350 \mathrm{~nm}$. Both studies showed that acetaldehyde and $\mathrm{CO}_{2}$ were the major products confirming what was reported earlier by Vesley and Leermakers at $366 \mathrm{~nm}$ [16]. Recently, Winterhalter et al. [7] conducted a series of experiments using the EUPHORE outdoor smog chamber and observed in addition to acetaldehyde, the formation of acetic acid, formic acid, formaldehyde, $\mathrm{CO}$ and vinyl alcohol (which rearranges to acetaldehyde). The suggested primary photolysis processes derived from the previous studies are:

$$
\begin{aligned}
& \mathrm{CH}_{3} \mathrm{C}(\mathrm{O}) \mathrm{C}(\mathrm{O}) \mathrm{OH} \rightarrow \mathrm{CH}_{3} \mathrm{CHO}+\mathrm{CO}_{2} \\
& \mathrm{CH}_{3} \mathrm{C}(\mathrm{O}) \mathrm{C}(\mathrm{O}) \mathrm{OH} \rightarrow \mathrm{CH}_{3} \mathrm{CO}+\mathrm{COOH} \\
& \mathrm{CH}_{3} \mathrm{C}(\mathrm{O}) \mathrm{C}(\mathrm{O}) \mathrm{OH} \rightarrow \mathrm{CH}_{3} \mathrm{C}(\mathrm{O}) \mathrm{OH}+\mathrm{CO}
\end{aligned}
$$

Winterhalter et al. [7] suggested that channel (7) is the major pathway $(\approx 50 \%)$ while channels $(8)$ and $(9)$ represent $\approx 30$ and $\approx 10 \%$, respectively. The present work shows the occurrence of another channel leading to the direct formation of $\mathrm{OH}$ radicals which could be:

$\mathrm{CH}_{3} \mathrm{C}(\mathrm{O}) \mathrm{C}(\mathrm{O}) \mathrm{OH} \rightarrow \mathrm{CH}_{3} \mathrm{CO}+\mathrm{CO}+\mathrm{OH}$

\section{Conclusions}

This work confirms that pyruvic acid is lost in the atmosphere in the gas phase mainly through photolysis since its reaction with $\mathrm{OH}$ radicals is slow $\left(k_{\mathrm{PA}}=(1.2 \pm 0.4) \times\right.$ $10^{-13} \mathrm{~cm}^{3}$ molecule ${ }^{-1} \mathrm{~s}^{-1}$ at $298 \mathrm{~K}$ ). The average lifetime of PA in the atmosphere with respect to the reaction with $\mathrm{OH}$ is estimated to be more than 3 months (assuming an $\mathrm{OH}$ concentration of $10^{6} \mathrm{~cm}^{-3}$ ) while that with respect to the photolysis is of few hours [7]. The direct detection of $\mathrm{OH}$ radicals by LIF following the photolysis of PA at $355 \mathrm{~nm}$ and its indirect detection through smog chamber studies using black lamps (300-460 nm) indicate the existence of another radicals forming channel from the photolysis of pyruvic acid. These observations are of atmospheric importance since pyruvic acid can be a source of radicals in remote area. The photolysis of organic acids with a comparable structure to that of pyruvic acid may also lead to the formation of radicals. More experimental and theoretical work is needed to understand the photolysis processes leading to $\mathrm{OH}$ radicals from the atmospheric photolysis of such compounds.

\section{Acknowledgements}

French Ministry of Environment through Primequal-Predit Program, Programme de Recherches Avancées de Coopération Franco-Chinoise (PRA), and National Science Foundation of China (Grant no. 29707004) are acknowledged for support. The authors gratefully acknowledge R. Winterhalter and N. Jensen for helpful discussion.

\section{References}

[1] M.O. Andreae, R.W. Talbot, S.M. Li, J. Geophys. Res. 92 (1987) 6635.

[2] K. Kawamura, H. Kasukabe, L.A. Barrie, Atmos. Environ. 30 (1996) 1709.

[3] E.D. Baboukas, M. Kanakidou, N. Mihalopoulos, J. Geophys. Res. 105 (2000) 14459.

[4] D.J. Jacob, S.C. Wofsy, Photochemical production of carboxylic acids in remote continental atmosphere, in: M.H. Unsworth (Ed.), Acid Deposition Processes at High Elevation Sites, Reidel, Hinghan, MA, 1988, pp. 73-92.

[5] R.W. Talbot, M.O. Andreae, H. Berresheim, D.J. Jacob, K.M. Beecher, J. Geophys. Res. 95 (1990) 16799.

[6] D. Grosjean, Atmos. Environ. 17 (1983) 2379.

[7] R. Winterhalter, N.R. Jensen, I. Magneron, K. Wirtz, A. Mellouki, Y. Mu, Y. Tadic, A. Horowitz, G.K. Moortgat, J. Hjorth, in: P.M. Midgley, M. Reuther, M. Williams (Eds.), Proceedings of the EUROTRAC-2 Symposium 2000, Springer, Berlin, 2001.

[8] A. Mellouki, S. Téton, G. Le Bras, Int. J. Chem. Kinet. 27 (1995) 791

[9] Y. Mu, A. Mellouki, J. Photochem. Photobiol. A: Chem. 134 (2000) 31.

[10] S. Yamamoto, R.A. Back, Can. J. Chem. 63 (1985) 549.

[11] A. Horowitz, R. Meller, G.K. Moortgat, J. Photochem. Photobiol. A: Chem. 146 (2001) 19.

[12] M.G.M. Berges, P. Warneck, Ber. Bunsenges. Phys. Chem. 96 (1992) 413.

[13] W.B. DeMore, S.P. Sander, D.M. Golden, R.F. Hampson, M.J. Kurylo, C.J. Howard, A.R. Ravishankara, C.E. Kolb, M.J. Molina, Chemical Kinetics and Photochemistry Data for Use in Stratospheric Modelling, JPL Publication 97-94.

[14] R. Atkinson, J. Phys. Chem. Ref. Data, Monogr. 2 (1994).

[15] T. Ohta, J. Phys. Chem. 87 (1983) 1209.

[16] G.F. Vesley, P.A. Leermarkers, J. Phys. Chem. 68 (1964) 2364. 